\title{
Leiomyosarcoma in a cockatiel
}

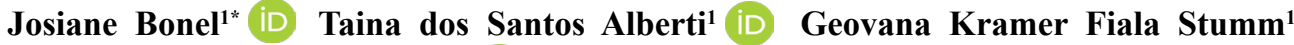 \\ Conrado de Oliveira Gamba ${ }^{2}$ iD Paulo Bandarra $^{3}$ Geovanni Dantas Cassali ${ }^{4}$ iD
}

\begin{abstract}
${ }^{1}$ Departamento de Patologia Animal, Faculdade de Veterinária, Universidade Federal de Pelotas (UFPel), Campus Capão do Leão, Campus Universitário, S/N, 96160-000, Capão do Leão, RS, Brasil. E-mail: josiebonnel@hotmail.com. *Corresponding author. ${ }^{2}$ Curso de Medicina Veterinária, Universidade do Oeste de Santa Catarina (UNOESC), Campos Novos, SC, Brasil. ${ }^{3}$ Núcleo de Reabilitação da Fauna Silvestre, Universidade Federal de Pelotas (UFPel), Campus Capão do Leão S/N, Capão do Leão, RS, Brasil. ${ }^{4}$ Laboratório de Patologia Comparada, Departamento de Patologia Geral, Instituto de Ciências Biológicas (ICB), Universidade Federal de Minas Gerais (UFMG), Belo Horizonte, MG, Brasil
\end{abstract}

ABSTRACT: Cockatiels (Nymphicus hollandicus) are exotic birds thatoriginated from Australia.Because of their beauty and learning ability, they are one of the most popular pet birds among the Psittaciformes. The objective of this study was to report a case of leiomyosarcoma on the humeral musculature of the left wing of a cockatiel (Nymphicus hollandicus). The animal was admitted to the Wildife Rehabilitation Center (NURFS-CETAS) of the Universidade Federal de Pelotas withswelling in the humeral region of the left wing. During surgery, the animal died and was transferred to the Laboratório Regional de Diagnóstico, Faculdade de Veterinária (LRD-UFPel). During histopathological evaluation (hematoxylin and eosin routine technique) of the tumor, spindle neoplastic cells were observed, arranged in interlaced bundles amongst degenerate and normal muscle fibers. Using immunohistochemistry, neoplastic cells were positively immunostained for vimentin and alpha smooth muscle actin. Based on of clinical-pathological and immunohistochemical findings, leiomyosarcoma was diagnosed.

Key words: psittaciformes, sarcomas, alpha actin, birds, vimentin.

\section{Leiomiossarcoma em calopsita}

RESUMO: As calopsitas (Nymphicus hollandicus) são aves exóticas originárias da Austrália. Devido a beleza e capacidade de aprendizado são uma das principais aves utilizadas como animal de companhia. O objetivo deste trabalho foi relatar um caso de leiomiossarcoma, na musculatura umeral da asa esquerda de uma calopsita. O animal deu entrada no Núcleo de Reabilitação da Fauna Silvestre (NURFS-CETAS) da Universidade Federal de Pelotas (UFPel), por apresentar aumento de volume na região umeral da asa esquerda. Durante o procedimento cirúrgico o animal veio a óbito, sendo encaminhado ao Laboratório Regional de Diagnóstico, Faculdade de Veterinária (LRD-UFPel). Na avaliação histopatológica (Técnica de rotina Hematoxilina e Eosina) da massa tumoral foram observadas células neoplásicas fusiformes, arranjadas em feixes entrelaçados, em meio a fibras musculares degeneradas e normais. Na imunohistoquímica verificou-se imunomarcação positiva das células neoplásicas para vimentina e alfa actina, de músculo liso. Diante dos achados clínico-patológicos e imunohistoquímicos determinou-se o diagnóstico de leiomiossarcoma. O diagnóstico definitivo deste neoplasma requer analise imunohistoquímica.

Palavras-chave: psitaciformes, sarcomas, alfa actina, aves, vimentina.

Cockatiels (Nymphicus hollandicus, Psittaciformes: Cacatuidae) are birds of Australian origin that live in flocks and are found mainly in subtropical and temperate regions. In Brazil, this species was only introduced in 1970 (CARVALHO, 2015).It is considered by the Brazilian Institute of Environment and Renewable Natural Resources (IBAMA)to be a domestic animal, which facilitates its rearing as a pet. It is the most widely-kept pet bird species because it exhibits docile and sociable behavior, diverse colors, intelligence, and ability to learn and reproduce sounds (GODOY, 2006). Among the Psittaciformes, this species has a relatively high prevalence of neoplasms (CASTRO et al., 2013). Numerous neoplasms are observed in pet birds, with a variety of presentations and aspects, but muscular neoplasms are rare (ARAÚJO et al., 2007). The greater longevity of captive birds and their constant exposure to environmental and nutritional carcinogens predispose them to neoplasia (GODOY et al., 2009).

This research had the objective to describe the diagnosis and characteristics of a leiomyosarcoma in a cockatiel (Nymphicus hollandicus) admitted at the Wildlife Rehabilitation Center (NURFS-CETAS) of the Federal University of Pelotas (UFPel) and necropsied at the Regional Diagnostic Laboratory - Faculty of Veterinary (LRD-UFPel).

A five-year-old cockatiel was admitted to NURFS-CETAS of the UFPel for treatment. The owner of the bird reported a lump in the left wing 
that had grown considerably in previous months. At clinical examination, the tumor was palpable and presented an area of ulceration with rarefaction of the surrounding feathers. Due to the size of the lump and its infiltration, the wing was amputated. During surgery, the bird died and was transferred to the LRDUFPel for necropsy.

Necropsy examination revealed a rounded tumor, approximately two centimeters in diameter, near the scapulohumeral joint, with firm, adherent consistency (Figure 1A). The lump involved much of the muscular tissue surrounding the humerus butdid not infiltrate the bone tissue. It was white and slightly firm, and adhered to the adjacent musculature. No macroscopic changes were observed in other organs. Fragments of the tumor and all organs were collected, fixed in 10\% buffered formalin, and routinely processed for histopathology. Sections were cut at $3 \mu \mathrm{m}$ thickness, stained with the trichrome and eosin (H\&E) routine technique and the special Masson's trichrome staining for later examination under an optical microscope. Histological evaluation of $\mathrm{H}$ $\&$ Estained tissue revealed spindle cell proliferation with basophilic nuclei, abundant undifferentiated cytoplasm, and rare mitosis figures (1-2 per high-power field $/ 400 \times)$ that were arranged in interlaced bundles

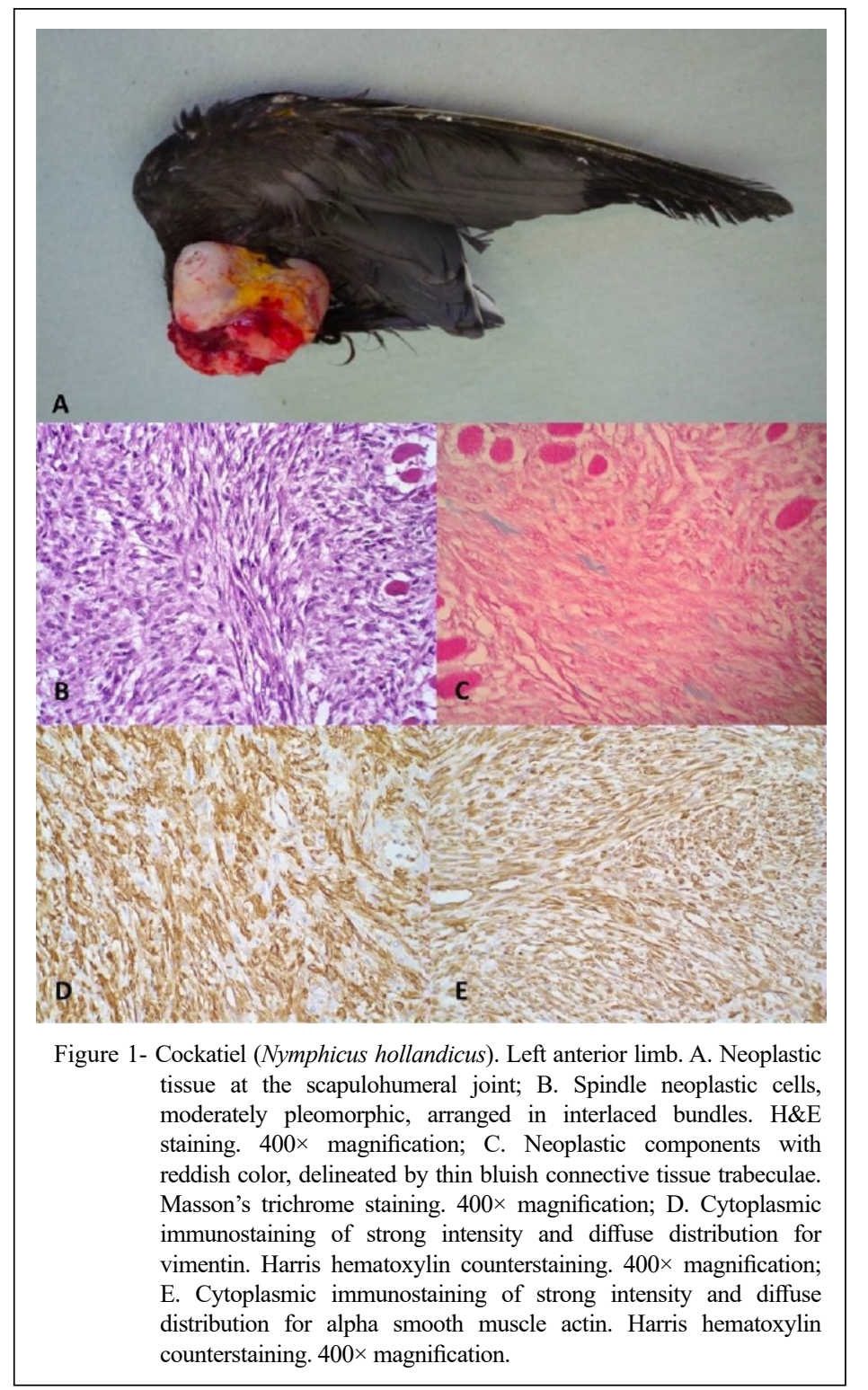

Ciência Rural, v.49, n.3, 2019. 
amongst degenerate and normal muscular fibers and scarce fibrous stroma (Figure 1B). The Masson's trichrome staining revealed reddish neoplastic components delineated by thin bluish connective tissue trabeculae (Figure 1C). Metastasis was not evident in the histopathological analysis. Together these histological findings suggested a mesenchymal neoplasm originating in the muscle tissue. We used immunohistochemistry to confirm this diagnosis.

For the immunohistochemical analysis, $3 \mu \mathrm{m}$ sections were mounted on gelatinized histological slides, and the peroxidase detection system Advance HRP $^{\circledR}$ (Dako, Carpinteria, California, USA) was used. Endogenous peroxidase activity was blocked using $3 \% \mathrm{H}_{2} \mathrm{O}_{2}$ diluted in methanol, reagents were applied manually, and the immunoreactivity was visualized by 3,3'-diaminobenzidine (Lab Vision DAB substrate system; Lab Vision, Fremont, California, USA). We used immunostaining for vimentin (clone V9, Dako, 1:50) and alpha smooth muscle actin (clone 1A4, Dako, $1: 100$ ), revealing intense and diffuse cytoplasmic stainingof the neoplastic cells for both vimentin (Figure 1D) and alpha smooth muscle actin (Figure 1E). Diagnosis of leiomyosarcoma was confirmed.

Among the main neoplasms observed in psittacines are lymphomas, cholangiomas, hemangiosarcomas, renal carcinomas and cholangiocarcinomas, with the latter most frequently diagnosed. Leiomyosarcoma is considered the most common muscular neoplasm in birds, but is more commonly reported in the smooth muscle trabeculae of the spleen (GODOY et al., 2009). In our case, the wing muscle tissue was the primary site of the leiomyosarcoma because neoplastic lesions were not observed in other organs. This is an uncommon localization of this tumor, with no other reports for cockatiels. Cutaneous tumors originating in smooth muscle are uncommon and are reported mainly in dogs and cats, possibly originating in the smooth muscle of the hair follicles (piloleiomyoma/ piloleiomyosarcoma) and/or vascular smooth muscle (angioleiomyoma/angioleiomyosarcoma) of the skin (HENDRICK, 2017).

Among differential diagnoses of leiomyosarcomas in birds, fibrosarcoma should be considered. These malignant neoplasms are commonly reported inwings and lower limbs as irregular ulcerated tissues that are firmly adhered to the skin (HENDRICK, 2017); and also neoplasms of muscular origin such as rhabdomyosarcomas.

The rhabdomyosarcomas originate from cells of the striated muscle tissue, which are locally invasive and visualized as raised, lobulated and relatively firm subcutaneous irregular tissues with greater occurrence in the wing region (ARAÚJO et al., 2007). According to the literature, the leiomyosarcoma macroscopically presents a large form with softened consistency (HENDRICK, 2017), unlike what was evidenced in the reported leiomyosarcoma.

In the present case study, H\&E staining showed muscle fibers that suggested the diagnosis of mesenchymal neoplasia, possibly of muscular origin. For differential diagnosis, we used the special Masson's trichrome staining, which aided visualization of muscle fibers within the neoplasia and ruled out the possibility of fibrosarcoma. However, this staining did not permit differentiation between leiomyosarcoma and rhabdomyosarcoma, necessitating immunohistochemical evaluation, which revealed neoplastic cells with intense and diffuse cytoplasmic immunoreactivity for vimentin and alpha smooth muscle actin. Taken together, our findings corroborate those of ALVES et al. (2015) who reported positive staining of leiomyosarcomas for vimentin, desmin, and alpha smooth muscle actin. Alpha smooth muscle actin is a potent marker for differentiation between smooth muscle and skeletal and cardiac striated muscles (COOPER \& VALENTINE (2017), confirmingour diagnosis of leiomyosarcoma.

TIMURKAAN et al. (2016) reported a case of cutaneous leiomyosarcoma at the base of the right wing of a five-year-old Australian Parakeet (Melopsittacus undulatus). As in the present report, the wing lesion was the only site of neoplasia, and confirmation of the diagnosis was based on immunohistochemistry. These authors also reported the presence of bone metaplasia, which we did not observe in the case of the cockatiel reported here. Three cases of leiomyosarcoma in the skin of female dogs were diagnosed through immunohistochemistry, one as piloleiomyosarcoma and two as angioleiomyosarcoma,but it was not possible to determine the primary origin of these tumors (JUNG et al., 2009).

Leiomyosarcomas are tumors that, depending on characteristics such as differentiation and mitotic index, can be classified as well- or poorlydifferentiated. Well-differentiated leiomyosarcomas are composed of spindle cells, with elongated nuclei, granular chromatin, and abundant eosinophilic cytoplasm presenting a fascicular interlacement. Poorlydifferentiated leiomyosarcomas are more cellular because of the scarcity of cytoplasm, with round to elongatecells and granular chromatin maintaining a fascicular interlaced pattern similar to that of the well-differentiated leiomyosarcoma (HENDRICK, 
2017). The neoplasm that we reportedcan probablybe categorized as a well-differentiated leiomyosarcoma, with a low mitotic index associated with slightly pleomorphic uniform cells.

We concluded that, based on the anatomopathological and immunohistochemical findings, the definitive diagnosis in this cockatiel was welldifferentiated leiomyosarcoma. Leiomyosarcoma is a neoplasia known to occur in cockatiels, and to reach the definitive diagnosis in uncertain cases, we recommend the use of complementary tests, particularly immunohistochemical analysis.

\section{ACKNOWLEDGEMENTS}

This study was financed in part by the Coordenação de Aperfeiçoamento de Pessoal de Nível Superior, Brasil (CAPES), Finance Code 001.

\section{DECLARATION \\ OF \\ CONFLICTING INTERESTS}

The authors declare no conflict of interest. The founding sponsors had no role in the design of the study; in the collection, analyses, or interpretation of data; in the writing of the manuscript, and in the decision to publish the results.

\section{AUTHORS' CONTRIBUTIONS}

All authors contributed equally for the conception and writing of the manuscript. All authors critically revised the manuscript and approved of the final version.

\section{REFERENCES}

ALVES, R.C.C.etal.Clinicopathological and immunohistochemical evaluation of oesophageal leiomyosarcoma in a dog. Ciência Rural, Santa Maria, v.45, n.9, p.1644-1647, set, 2015. Available from: $\quad<$ http://www.scielo.br/scielo.php?script=sci arttext\&pid $=$ S0103-84782015000901644>. Accessed: Mar. 15, 2017.

ARAÚJO, A.C.P. et al.Alveolar rhabdomyosarcoma in parrot (Amazona aestiva). Acta Scientiae Veterinariae, Porto Alegre, v.35, n.1, p.115-117, 2007. Available from:<https://lume.ufrgs.br/ handle/10183/20553>. Accessed: Mar. 15, 2017.

CARVALHO, T.S.G. et al. Behaviour of cockatiels (Nymphicus hollandicus) at two temperatures in captivity. Arquivo Brasileiro de Medicina Veterinária e Zootecnia, v.67, n.6, p.1669-1674, 2015. Available: $<$ http://www.scielo.br/scielo.php?script=sci arttext\&pid=S0102-09352015000601669\#B6>. Accessed: Feb. 12, 2019. EpubNov-Dez-2015. doi: 10.1590/1678-4162-7892.(Electronic publication).

CASTRO, P.F. et al. Retrospectivestudyofsurgicalconditions in birds. Pesquisa Veterinária Brasileira, Seropédica, v.33, n.5, p.662-668, 2013. Available from: <http://www.scielo.br/pdf/pvb/ v33n5/18>. Accessed: Mar. 16, 2017.

COOPER, B.J.; VALENTINE, B.A. Tumors of muscle. In: MEUTEN, D.J. Tumors in domestic animals. 5.ed. John Wiley \& Sons, Inc, 2017, p.425-466.

GODOY, S.N. et al.Main neoplastic processes found in psittacids kept in captivity. Pesquisa Veterinária Brasileira. v.29, n.6, p.445-451, junho, 2009. Available from: <http://www.scielo.br/ scielo.php?pid=S0100-736X2009000600001\&script=sci_abstract\&tlng=pt $>$ Accessed: Mar. 16, 2017.

GODOY, S.N. Psittaciformes (Arara, Papagaio, Periquito). In: CUBAS, Z.S.; SILVA, J.C.R.; CATÃO-DIAS, J.L. Tratado de Animais Selvagens - Medicina Veterinária. São Paulo: Roca, 2006. Cap.16, p.222-251.

HENDRICK, M.J. Mesenchymal tumors of the skin and soft tissues. In: MEUTEN, D.J. Tumors in domestic animals. 5.ed. John Wiley \& Sons, Inc, 2017. p.142-175.

JUNG, J. et al. Cutaneous smooth muscle tumors in 3 dogs. Korean J Vet Res, v.49, n.1, p.63-66, 2009. Available from: <http://kjvr. org/upload/06903909>. Available: Nov. 23, 2018.

SAUT, J.P.E. et al. Vaginal leiomyosarcoma in a cow from Uberlândia, Minas Gerais, Brazil. Ciência Rural, Santa Maria, v.43, n.5, p.897-901, mai, 2013. Available from: $<$ http://www.scielo.br/ scielo.php?script=sci_arttext\&pid=S0103-84782013000500024>. Accessed: Mar. 16, 2017.

TIMURKAAN, N. et al. Cutaneous leiomyosarcoma with osteoid metaplasia in a budgerigar (Melopsittacus undulatus): a case report. Veterinarni Medicina, v.61, n.9, p.533-537, 2016. Available from: $<$ http://vri.cz/docs/vetmed/61-9-533>. Accessed: Nov. 23, 2018. 